\title{
Long-term sustainability assessment of micro-hydro projects: Case studies from Venezuela
}

\author{
A. López-González ${ }^{1,2}$, L. Ferrer-Martí1 ${ }^{1,3 *}$, B. Domenech ${ }^{1,4}$ \\ ${ }^{1}$ Institute of Industrial and Control Engineering, Universitat Politècnica de Catalunya - BarcelonaTech (Spain) \\ ${ }^{2}$ Socioeconomic Center of Petroleum and Alternative Energies, Universidad del Zulia (Venezuela) \\ ${ }^{3}$ Department of Mechanical Engineering, Universitat Politècnica de Catalunya - BarcelonaTech (Spain) \\ ${ }^{4}$ Serra Hunter Fellow, Department of Management, Universitat Politècnica de Catalunya - BarcelonaTech (Spain) \\ Contact (*): Av. Diagonal 647, Pavilion F, Floor 0, 08028, Barcelona (Spain) \\ laia.ferrer@upc.edu ; (+34) 934.016.579
}

\begin{abstract}
In 2016, 1,100 million people lack access to electricity, mainly in developing countries in Africa, Asia and South America. In these countries, there is a large potential for hydroelectric production through off-grid microgrids, although not fully exploited. This work assesses the long-term sustainability of off-grid microhydro projects operating in rural indigenous communities. More specifically, four sustainability dimensions are analyzed: environmental, technical, socioeconomic and institutional, and specific indicators are proposed for each one. In particular, 6 micro-hydroelectric power plants in southern Venezuela are used as case studies. The data gathering includes surveys, technical visits and interviews with technicians, engineers and beneficiaries. Results show that the institutional dimension and, in particular, alignment between involved institutions has been fundamental for the long-term sustainability. Indeed, appropriate institutional alignment is the key to strengthening the impacts on: (i) the environmental dimension, minimizing emissions and impacts on local ecosystems; (ii) the technical dimension, improving adequacy and reliability of technologies; and (iii) the socioeconomic dimension, making efficient use of electricity to enhance education, health and productivity. Lessons learned and conclusions of this research can significantly contribute to improve future projects, in particular to the 22 included in the electrification plans of Venezuela in coming years.
\end{abstract}

\section{Keywords}


Rural electrification, micro-hydroelectric power plants, long-term sustainability assessment, developing countries, Venezuela.

\section{INTRODUCTION}

In 20161,100 million people lack access to electricity, which represents almost a fifth of the world population (IEA, 2017). Most of these people live in the poorest rural areas of the world, where the dispersion of houses, long distances to urban centers and the geographical characteristics of territory make extending the electrical network difficult. To give this population access to electricity, diesel technology, prior to the $21^{\text {st }}$ century, was the most widespread option for rural electrification in developing countries (López-González et al., 2018b). However, some technologies based on renewable energy, such as micro-hydroelectric power plants (MHP), can be cheaper than diesel generators while providing a better service quality. Therefore, they represent an appropriate solution, increasing access to efficient and affordable electricity and contributing to poverty reduction and mitigation of climate change (Yadoo and Cruickshank, 2012). In this sense, the use of renewable energy for off-grid rural electrification has been increasing so that, from 2007 to 2016,300 million people in 60 million houses received electricity through these technologies (IRENA, 2017).

Renewable energy resources are not evenly distributed throughout the world, but each region has some noteworthy resource (Sachdev et al., 2015). The main energy sources for rural electrification are solar, wind and hydro, although they have some limitations, mainly their dependence on natural cycles. For example, solar photovoltaic (PV) does not work at night and wind energy can be very variable, so both options need battery storage, while hydropower requires continuous water flow. Even though micro-hydroelectric power plants (MHP) may need a diesel backup for drought periods, the equipment and technology are more affordable and the cost of power generation is lower than for other technologies (Khan, 2015). Commonly, hydro projects can have negative environmental impacts, mainly concerning flooding of fertile land (Abbasi and Abbasi, 2011) (Pang et al., 2015) (Lakhanpal, 2018). However, the micro-hydro projects focused in this paper are very small facilities that usually do not have significant impacts in land use. Indeed, experience has shown that microhydro systems have the longest lifetime, being the most reliable, ecological and robust renewable electrification technology (Paish, 2002). In addition, these projects have usually proven to be socially assimilated by rural populations (Sharma and Thakur, 2015). 
At a global level, there is a potential for electricity generation using MHP of around 1,787 TWh/year. Most of this potential (80.1\%) can be found in developing countries in Africa, Asia and South America (Blanco et al., 2008). While industrialized regions such as Europe and North America have taken advantage of $45.7 \%$ and $18.7 \%$ of their small-scale hydroelectric potential, these values are only $1.9 \%, 6.9 \%$ and $8.1 \%$ in Africa, Asia and South America, respectively (Jia et al., 2017). It is precisely these regions that have the largest percentage of people lacking access to electricity (IEA, 2017). Indeed, many rural villages without electricity in Africa and South America are located close to rivers that could be used for electricity generation (Torres et al., 2007). However, the electrification rates with MHP are related to institutional and economic development and are lower than in developed regions (Jimenez, 2017). The critical issue, at the beginning of this century, was the high investment cost (Khennas and Barnett, 2000), which did not benefit MHP in cost-based comparisons. Therefore, it was essential, and it is still necessary, to increase the awareness among decision-makers about the social, economic and environmental advantages of electrification through MHP (Pigaht and van der Plas, 2009).

Although extensive research has been carried out on hydroelectric generation, it mostly looks at medium or large power plants (Jawahar and Michael, 2017). Regarding MHP, investigations focus on technical aspects (Bracken et al., 2014), while the long-term sustainability has not yet been the subject of empirical analysis (Drinkwaard et al., 2010). Indeed, despite the large number of rural electrification projects carried out in developing countries, there are few empirical evaluations (Ilskog, 2008). Exceptionally, Yadoo and Cruickshank (2012) and Lillo et al. (2015a) analyze rural electrification systems with MHP, particularly focusing on the management model. Recently, a comparative analysis of renewable energy-based projects in Andean countries and microgrid-based projects in Venezuela has been developed (López-González et al., 2017; López-Gonzalez et al., 2018a). However, very few studies have been published about the evaluation of all the sustainability dimensions in communities benefited by electrification projects with renewable energy (van de Walle et al., 2013). In particular, there is very little research on empirical long-term evaluation of community electrification projects in situ (Terrapon-Pfaff et al., 2014). In this regard, López-González et al. (2018b) highlight the importance of evaluation after several years of operation, but they focus on diesel-based projects. 
In this context, it is necessary to develop further research regarding MHP rural electrification projects, covering the lifetime of key components such as civil works, powerhouse, generator, electromechanical equipment and the distribution network. Specifically, assessment must include broad criteria for evaluating the social, economic, environmental and institutional dimensions of the local environment of MHP projects (Schnitzer, 2014). Indeed, sustainability is related to the resilience of off-grid renewable energy systems, i.e. their capacity to remain in good working order under changing conditions (Serru, 2014). Hence, the purpose of this research is to evaluate the long-term sustainability of MHP rural electrification projects in remote communities. Previously, Cottrell et al (2013) proposed four dimensions for the sustainability assessment: environmental, economic, socio-cultural, and institutional. Others like Ilskog (2008) proposed five dimensions. In this research, the technical dimension is needed in order to carry out a wide assessment of projects, so the fourdimension method proposed by López-González et al. (2018a) is used: environmental, technical, socioeconomic and institutional. For each dimension, some criteria are established to analyze different aspects of MHP projects. In particular, 6 MHP projects in "La Gran Sabana" of Venezuela are evaluated, which have been operative for 20 to 60 years. First, data from monthly reports of the state company that manages the projects is analyzed. In addition, the projects are visited and household surveys are conducted, as well as interviews with representatives of community organizations and the sociopolitical structure of communities. The results allow identification of the key aspects to consider for the improvement of future MHP projects, particularly in Venezuela, where the development of 22 new ones is planned in coming years.

The remainder of the paper is organized as follows. In Section 2, the projects' design is described, as well as the technical aspects and their performance. Section 3 describes the assessment method to evaluate the longterm sustainability of MHP projects, as well as the results for each dimension, based on the criteria defined. In Section 4, the obtained results are discussed. Finally, the main conclusions are summarized in Section 5.

\section{PROJECTS' DESCRIPTION}

The potential for MHP in Venezuela is approximately 4,400 MW, which corresponds to $7 \%$ of the total hydroelectric potential of the country (INE, 2017). $76 \%$ of this potential remains unexploited throughout the Orinoco and Caroní river basins (Bolívar and Amazonas states), 18\% in the Andean region (Mérida, Trujillo and Táchira states), and 6\% in the Sierra de Perijá (Zulia state) (Fundelec, 2015). Electrification by MHP in 
Venezuela has had, as its main objectives, the saving of fossil energy resources that, otherwise, would be have been consumed, while diversifying the energy matrix and avoiding pollution in fragile ecosystems. In southern Venezuela, electricity generation through MHP has been centered on communities located in important river basins such as Caroní. A design premise is the conservation of the Caroní river basin, from which $65 \%$ of the national electricity consumption is generated through large plants (REN21, 2016). Caroní, with an average flow of $3,514 \mathrm{~m}^{3} / \mathrm{s}$, represents $75 \%$ of Venezuela's hydroelectric potential (Rodrígez-Betancourt et al., 2000), which has been estimated at around $63.000 \mathrm{MW}$.

The Caroní river basin and its tributaries are mostly within "La Gran Sabana", which is inside Canaima national park. Since 1957, 6 indigenous communities have been electrified and environmentally friendly development programs have been launched (Table 1): Kavanayén, Kamarata, Wonken, Arautamerú, La Ciudadela and Canaima. The MHP projects are supported by a diesel backup system to partially cover the demand in the case of long failures or drought periods, generally from January to March (Smith and Ubilava, 2017). Figure 1 shows the location of the 6 communities and MHP projects.

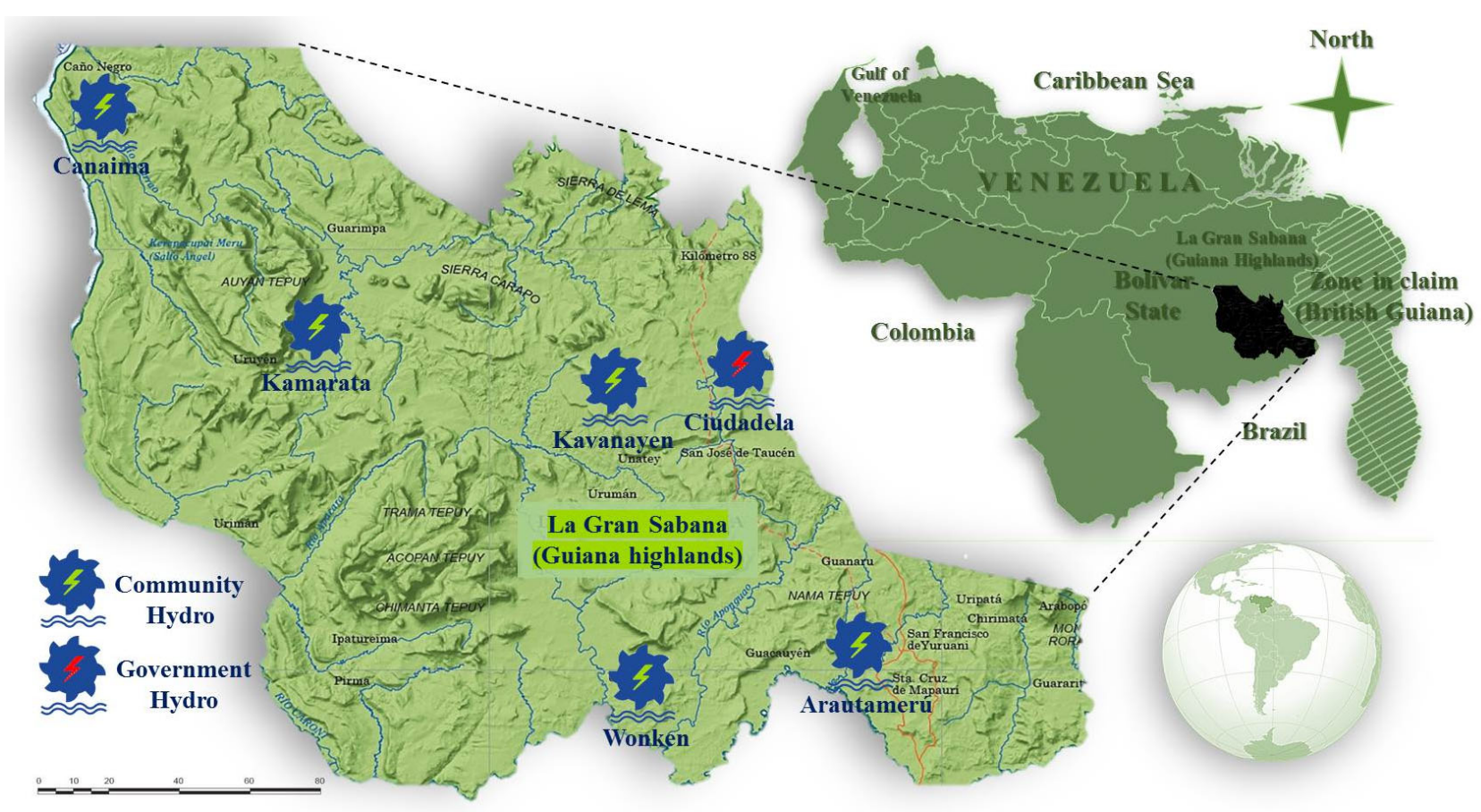

Figure 1. Location of the MHP projects in La Gran Sabana (southern Venezuela) 
Table 1. Description of the MHP projects in La Gran Sabana (southern Venezuela)

\begin{tabular}{|c|c|c|c|c|c|}
\hline Community & $\begin{array}{c}\text { Year of } \\
\text { installation }\end{array}$ & Houses & $\begin{array}{c}\text { Beneficiaries } \\
\text { (people) }\end{array}$ & Technology & $\begin{array}{c}\text { Installed capacity }(\mathrm{kW}) \\
\text { and units }\end{array}$ \\
\hline Kavanayen & 1957 & 300 & 1200 & Francis & $110(1 \times 110)$ \\
\hline Kamarata & 1962 & 145 & 800 & Francis & $60(1 \times 60)$ \\
\hline Wonken & 1984 & 180 & 600 & Banki-Edelca (I) & $58(1 \times 58)$ \\
\hline Arautamerú & 1988 & 300 & 1200 & Banki-Edelca (II) & $150(6 \times 25)$ \\
\hline La Ciudadela & 1994 & 120 & 350 & Banki-Edelca (III) & $120(2 \times 60)$ \\
\hline Canaima & 1994 & 280 & 1000 & Banki-Edelca (III) & $400(1 \times 400)$ \\
\hline
\end{tabular}

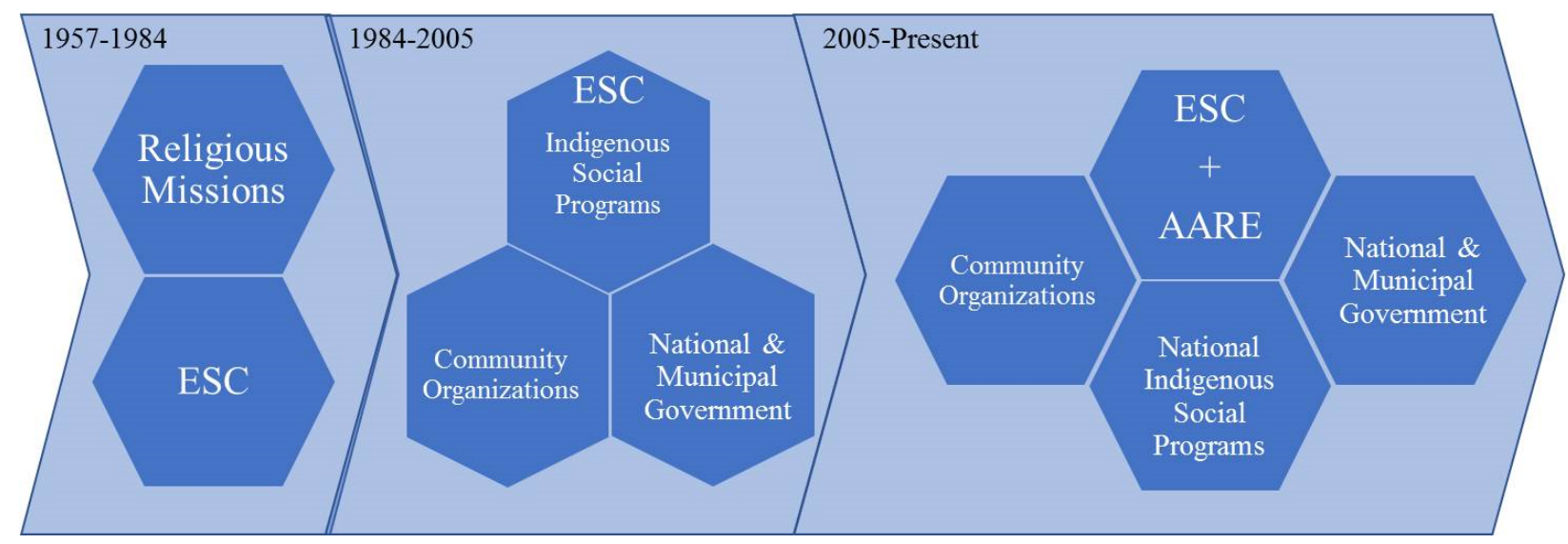

Figure 2. Evolution of the management model of the electrified communities with MHP

The model for sustainable institutional management of Renewable Energy Technologies (RET) based rural electrification systems is a key to avoiding high failure rates (Gollwitzer et al., 2018). In these projects, there have been three stages of management model and a long-term electrification policy including a progressively aligning the institutions involved (Figure 2). It should be noted that the six communities belong to the Pemón indigenous ethnic group, whose social characteristics were considered in the design of the management model. In particular, the indigenous authorities and the indigenous chieftain, an elder of the community elected by the other elders, were included.

In the first MHP (Kavanayén, Kamarata and Wonken), the electrification systems were developed by Catholic missionaries (Religious Missions) in 1957, with institutional support from the national government rural electrification policy through the Electrical Service Company (ESC). This had a positive impact, as technical schools were promoted by missionary teachers and funding by both the government and the ecclesiastical 
authorities. These schools provided literacy and education in areas such as agriculture, crafts and construction. Religious missionaries technically designed the MHP and worked together with the local population on the civil works, while ESC provided electrical and mechanical engineers for the technical supervision. Management and maintenance of the MHP was carried out by the religious missions.

Since 1984, ESC became directly involved in the operation and maintenance of the first projects, through Indigenous Social Programs (ESC-Indigenous Social Programs, called Mayú). Indeed, ESC developed a special program to support the management of the MHP, replacing the religious missions. In addition, ESC implemented new projects (Arautamerú, La Ciudadela and Canaima) together with the National and Municipal governments as well as Community Organizations and Indigenous Social Programs.

In 2005, Indigenous Social Programs made the Community Organizations completely operative and trained them to assume projects' management, in collaboration with ESC and the National Government through an Autonomous Authority for Rural Electrification (ESC+AARE). The ESC-Indigenous Social Programs were transformed into National Indigenous Social Programs with a national scope; National and Municipal governments are still involved. Nowadays, in the 6 communities there is a shared management model, where $\mathrm{ESC}$ is responsible for the maintenance of equipment and users pay a fee (all houses have consumption meters) and are responsible for the rational and efficient use of energy in order to extend projects' lifetime. Users were trained on the efficient energy usage through workshops promoted by the ESC. In addition, according to Ministry of Electrical Energy of Venezuela (MPPEE, 2013), from 2006 to 2012 the national electricity company distributed 156.845.182 low-consumption light bulbs completely free for people living in poor, rural and indigenous communities. The indigenous chieftains and Community Organizations act as representatives to ESC and other public institutions of Venezuela.

In these communities, the development process started almost at the same time as the MHP rural electrification projects. At the beginning, these small settlements, scattered over large areas, concentrated around population centers being electrified. Then, the acquisition of new agricultural techniques and the use of electricity for irrigation, lighting, education and health, among others, enabled progressive growth in the number of houses. Thanks to electrification, there are currently no significant social nor political differences between these communities and any other rural community in Venezuela. 
The remainder of this section is organized to explain each of the six communities as follows: (i) in the first paragraph, a general presentation of the community and the corresponding MHP project; (ii) in the second paragraph, a description of the project design and its performance, considering historical records stored in the Corporación Venezolana de Guayana (CVG) library (EDELCA, 2006), located in Puerto Ordáz, Bolivar State (southern Venezuela).

\subsection{Kavanayén}

The community of Kavanayén is located $55.7 \mathrm{~km}$ from the trunk road of La Gran Sabana, at an altitude of 1,200 m.a.s.l. in a territory with a highly fragile ecosystem (Torres et al., 2007). The closest village is Luepa (La Ciudadela), located $40.8 \mathrm{~km}$ away, and the next city electrified through the national grid is $210 \mathrm{~km}$ away. The community grew around a Capuchin mission established in 1940 (Gutierrez-Salazar, 2004) and currently has 1,200 inhabitants and 300 houses distributed over an area of 215 ha. $100 \%$ of the houses have obtained electricity and water since 1957 from the Apacairo River, which is a tributary of the Caroní River (Figure 3A). Currently, in the community there is a mission-school, a secondary school, a health center, several tourist inns, restaurants, tour operators and the MHP operations center (Figure 3-B). Moreover, there is a monitoring center for all the MHP of the region, and communication is maintained with the regional headquarters of the ESC in Ciudad Guayana, $350 \mathrm{~km}$ to the north.

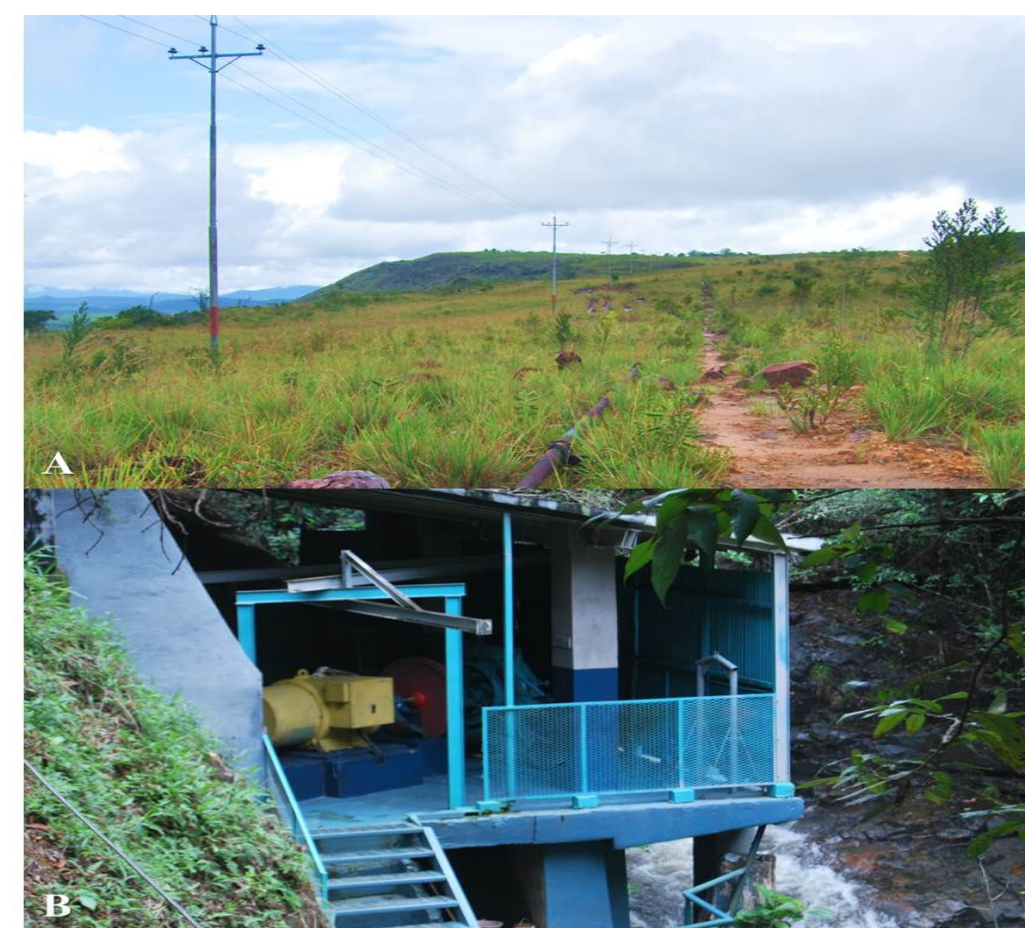

Figure 3. (A) Power and water lines from Apacairo; (B) MHP operations center in Kavanayén 
The MHP of Kavanayén was conceived by Capuchin missionaries and was put into operation through the collaboration with the government of Venezuela. Venezuelan engineers conducted the topographic surveys, design and construction instructions, while the physical work was performed by the indigenous population and missionaries. The MHP has worked continuously for 60 years, generating around 210,818 kWh/year (EDELCA, 2008), which means a capacity factor of $22 \%$ (rate between actual and potential generation). In 1994, the original turbine (EDELCA, 1995) was replaced by a $125 \mathrm{~kW}$ turbo-generator system (CORPOELEC, 2014).

\subsection{Kamarata}

Kamarata is $70 \mathrm{~km}$ away from Kavanayén and can only be reached by air. The community is located in the western area of Canaima National Park in Bolívar State near the Auyán-Tepui (Angel Falls), which is the most important tourist destination in southern Venezuela. It has 1,500 inhabitants distributed in 12 small and dispersed settlements, where people are mainly engaged in tourism and agriculture. Like Kavanayén, it was founded by Capuchin missionaries who settled in the Kamarata Valley in 1954 (Gutierrez-Salazar, 2004). These missionaries conceived the MHP project that started operations in 1962, in a ravine of the river Tapere (Figure 4). In the main settlement, there are 145 electrified houses and 800 people (100\% of the population), a mission-school, a primary school, a secondary school, a clinic, a tour operator, inns and restaurants. Scattered houses outside the main settlement are electrified using solar PV modules.

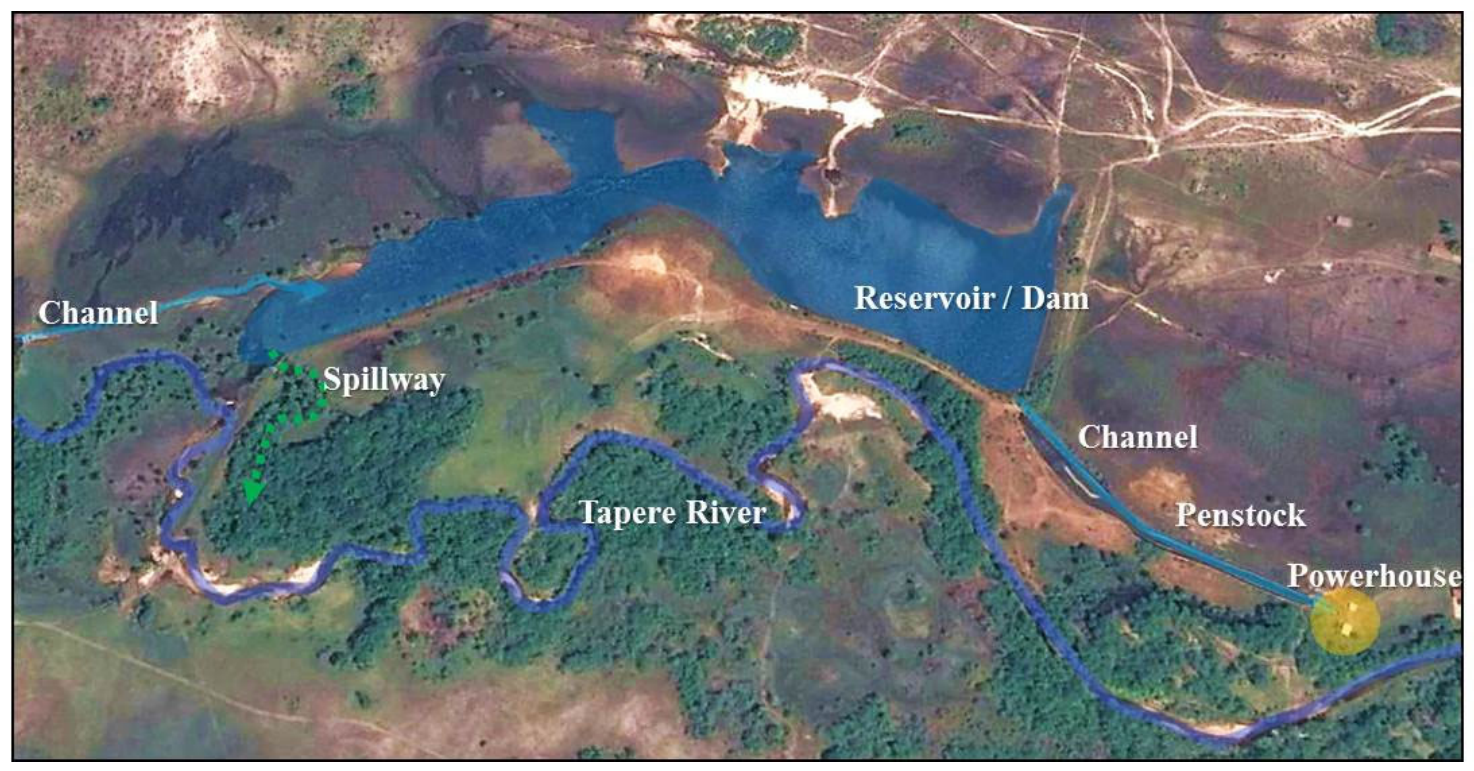

Figure 4. Satellite image of Kamarata MHP 
The Kamarata MHP was conceived by Capuchin missionaries and was put into operation with the support of engineers from the Caracas electricity company. The MHP has worked for 55 years during which there have been some periods of unavailability because of long dry seasons related to "El Niño Southern Oscillation" (ENSO). This phenomenon is intensified by the global warming and climate change (Smith and Ubilava, 2017). In recent years, the MHP has generated around 50,289 kWh/year (EDELCA, 2008), which implies a capacity factor of $9.6 \%$. This poor performance has been caused by the low water supply as a consequence of dam breakage, causing a water loss of almost $45 \%$ and a generation capacity barely reaching $27 \mathrm{~kW}$. The dam break has also led to the entrance of sediments into the reservoir, reducing the generating capacity due to the proliferation of aquatic plants. In addition, on several occasions, the heavy rains in August and September have caused severe damage to the headrace channel adjacent to the powerhouse. Moreover, given its length and prolonged lifetime, the channel has leaks that increase during rainy periods. Therefore, the uneven flow of the channel is insufficient for electricity generation from January to March. At highest demand hours, the farthest houses of the distribution network have voltage fluctuations intensified by the significant losses in the deteriorated lines. Under normal operating conditions, the average annual electricity generation could reach up to $120,000 \mathrm{kWh} /$ year and the capacity factor would be around $22.8 \%$.

\subsection{Wonken}

The community of Wonken is located $65 \mathrm{~km}$ from the trunk road of La Gran Sabana, from the Sierra Lema to the border with Brazil. Access to Wonken is only possible by four-wheel drive vehicles. The community grew up in the surroundings of a Catholic missionary center established in 1959 (Angosto-Fernández, 2013). In general, the shape, character and size of the settlements have significantly changed during the last century, especially since electrification. The initial 150 inhabitants in scattered houses began to settle around the mission in order to get access to the schools and productive activities (Angosto-Fernández, 2013). Nowadays, 600 people live in Wonken, benefiting from the electricity service.

In the 1970s an initial MHP was built by missionaries along with the indigenous population. The machinery, as well as some civil works, still remains. Afterwards, in 1984, the first Banki unit was installed. The Banki turbine was designed and built entirely by Venezuelan EDELCA engineers in the metal-mechanical workshops of the Caroní hydroelectric complex, in the north of Bolívar state. The main advantages of the Banki-Edelca 
turbine are the weight, cost and maintenance reduction, thanks to technical improvements. In particular, the Banki-Edelca turbine, based on the first machines installed by the missionaries, provided useful experience towards the manufacture of the six Banki-Edelca turbines for the Arautamerú MHP (section 2.4). After 30 years of operation, it has demonstrated high reliability and performance levels. In recent years, the MHP has generated around 174,838 kWh/year (EDELCA, 2008), which implies a capacity factor of $34.4 \%$.

\subsection{Arautamerú}

The MHP of Arautamerú was installed in 1988, is located $3.5 \mathrm{~km}$ from the trunk road and supplies electricity to two settlements: San Francisco de Yuruaní and San Ignacio de Yuruaní. San Francisco de Yuruaní has 1,650 inhabitants, 150 houses and is $3.9 \mathrm{~km}$ away from the MHP. Its proximity to the Roraima makes it the meeting point for all tourist expeditions to the Tepuy; its main productive activity is tourism. Inns have been established thanks to electricity access. San Ignacio de Yuruaní has 460 inhabitants and 82 houses and is $4.6 \mathrm{~km}$ away from the MHP. San Ignacio de Yuruaní grew up around an operation center building of the electricity company, although the main economic activity is tourism.

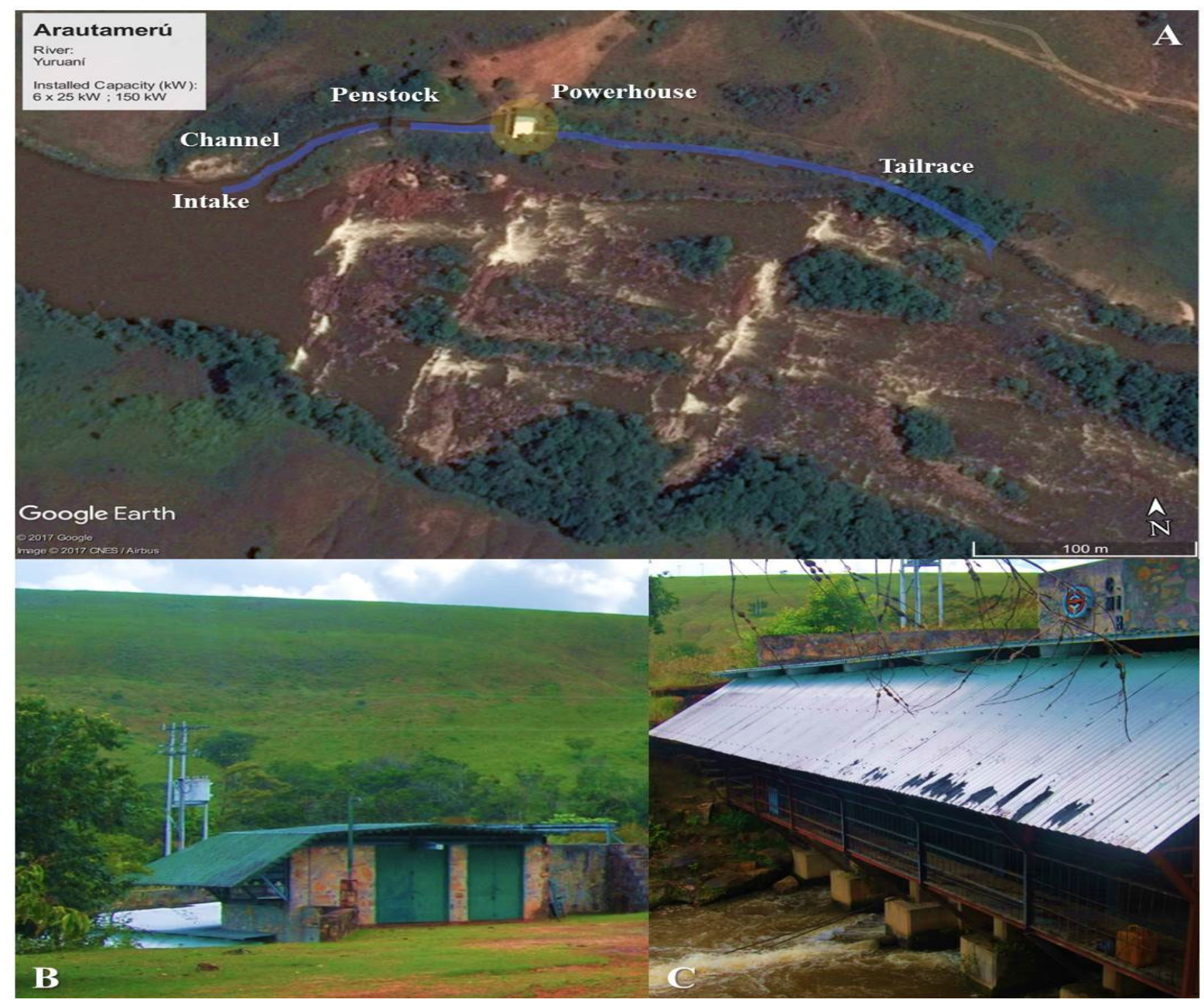

Figure 5. (A) Satellite image of Arautamerú micro-central (B) Powerhouse (C) Drain 
The MHP of Arautamerú was designed by the electric company EDELCA based on the experiences of the MHPs previously developed in Kavanayén, Kamarata and Wonken (Figure 5-A). The Arautamerú turbines were among the first designed by EDELCA after the Wonken project (see section 2.3). The Arautamerú units are fully adapted to the environment they serve, without causing a negative visual impact, using local construction materials obtained from the community surroundings (Figure 5-B, Figure 5-C). Based on these experiences, a national methodology for the design of turbines, which were technically and economically competitive at an international level, was developed (EDELCA, 1991). Indeed, the development of BankiEdelca turbines was the first initiative of its kind in Latin America (Barei, 1994). The MHP has worked for almost 30 years during which there have been no prolonged periods of unavailability. Electricity rationing has generally happened during exceptionally long droughts, which never lasted more than a month (Smith and Ubilava, 2017). The inns and restaurants have their own generators, to guarantee 24 hour service. The electricity demand of San Francisco has grown much faster than the capacity of the MHP. In this regard, since the beginning of operations in 1988, technical modifications have been made to four of the six turbines (EDELCA, 1996). However, at peak demand hours, the distribution network is very susceptible to failures and instability due to voltage fluctuations derived from atmospheric discharges. In recent years, the MHP has generated around 572,968 kWh/year (EDELCA, 2008), which implies a capacity factor of $43.6 \%$. San Ignacio and San Francisco represent around $20 \%$ and $80 \%$ of the load, respectively.

\subsection{La Ciudadela}

The MHP of La Ciudadela is located on the banks of the Aponguao river, very close to the trunk road of La Gran Sabana at the foot of the Lema Sierra, which is the natural entrance barrier to La Gran Sabana. The project became operational in 1994, electrifying the workers' camp and heliport of EDELCA, as well as the headquarters and barracks of a Venezuelan army battalion in the border area of Luepa. Currently, 580 people, as well as an office of the National Institute of Parks (Inparques) and a tourist center, benefit from electricity.

The turbines of La Ciudadela are more sophisticated versions of the Banki-Edelca turbines, having a totally hermetic seal that had not previously been achieved in available commercial versions of Banki turbines. In recent years, the MHP has generated around 436,668 $\mathrm{kWh} /$ year (EDELCA, 2008), which implies a capacity 
factor of $32.6 \%$. The Aponguao river is one of the most abundant in La Gran Sabana and, therefore, less susceptible to droughts during dry seasons.

\subsection{Canaima}

Canaima is $75 \mathrm{~km}$ away from Kavanayén and $165 \mathrm{~km}$ from the trunk road of La Gran Sabana, and can only be accessed by air. Canaima is located in La Gran Sabana (Canaima National Park) and is one of the most important tourist destinations in Venezuela, especially for foreigners. It has 1,000 inhabitants and people are mainly engaged in tourism. The community has an airport, a heliport and hotel services. Canaima MHP became operational in 1994 and is located on the banks of the Carrao river (Figure 6-A)

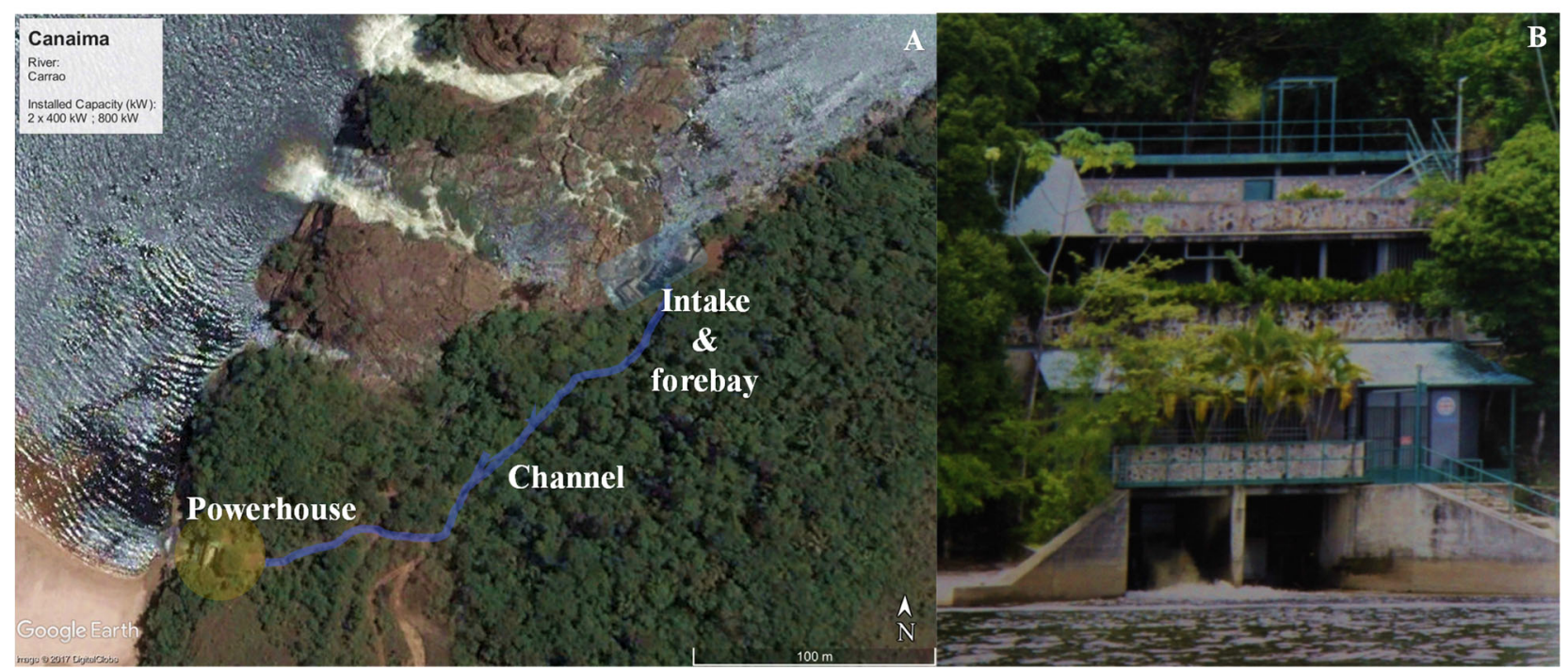

Figure 6. (A) Satellite image of Canaima micro-central (B) Powerhouse

The MHP was designed to minimize its visual impact (Figure 6-B). The turbine is a Banki-Edelca with 400 kW capacity (CORPOELEC, 2014) which has several operational advances in comparison with the previous versions, in order to reduce premature wear and unnecessary leakage (Barei, 1994). In recent years, the MHP has generated about $1,678,073 \mathrm{kWh} /$ year [33], which implies a capacity factor of $47.9 \%$. In addition, a system was implemented that allows some aspects to be monitored from Ciudad Guayana, such as voltage, power and temperature of equipment (EDELCA, 1996). 


\section{Evaluation Methodology}

In order to evaluate the long-term sustainability of the projects, four key dimensions for rural electrification projects are assessed, according to the definitions from López-González et al. (2018a): environmental, technical, socioeconomic and institutional. In order to assess the long-term sustainability, different criteria are proposed for each dimension, which may be evaluated qualitatively or quantitatively. The criteria are defined according to the Sustainable Development Goals established in the 2030 Agenda of the United Nations (UN, 2015), taking into account the opinion of technicians of the Electricity Ministry of Venezuela. A total of 8 criteria are defined (Figure 7): emission mitigation, impact on local ecosystems, adequacy, reliability, education, health, productivity and institutional and policies alignment. These criteria are sufficiently robust and flexible to be easily used in other regions and countries (Ilskog, 2008).

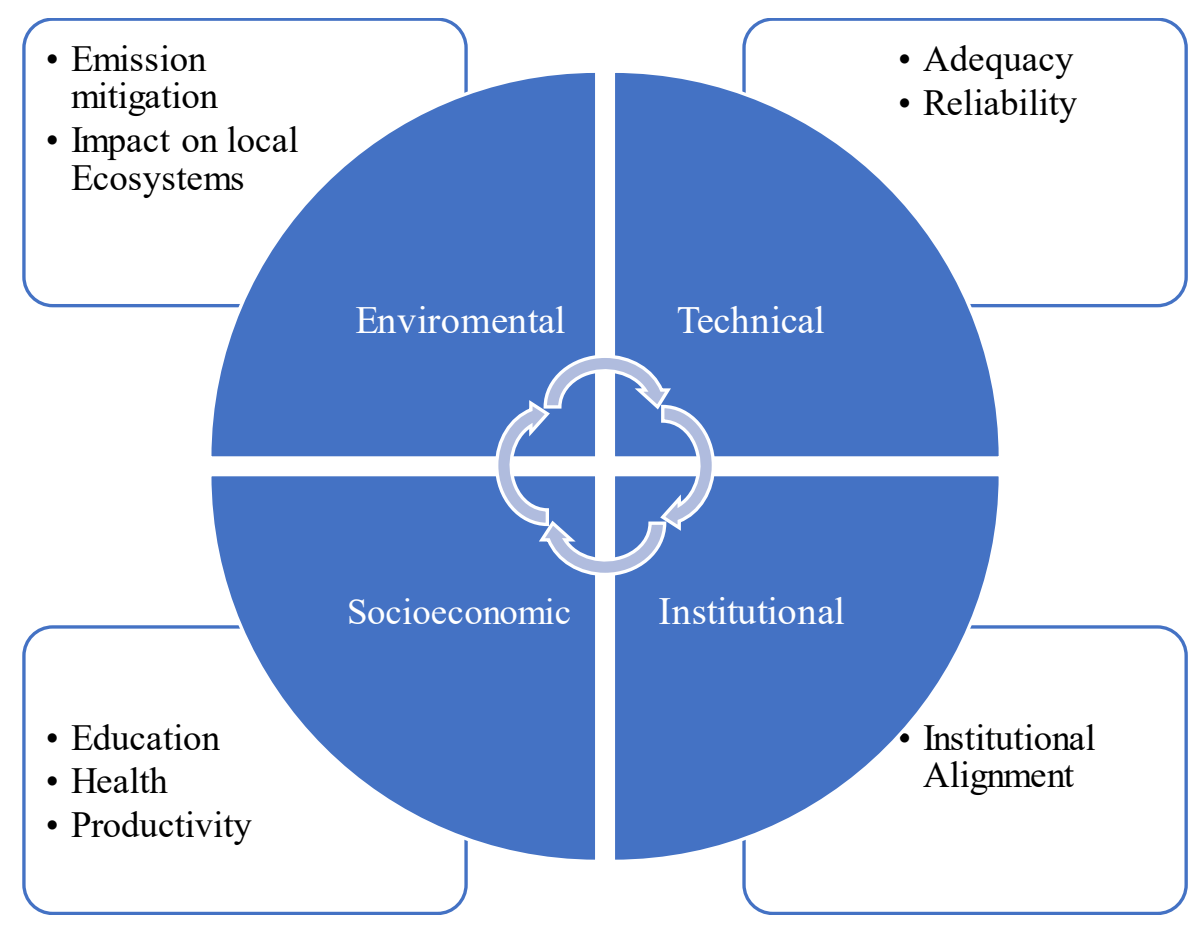

Figure 7. Sustainability assessment proposed dimensions and criteria

Next, the data gathering methods and the fieldwork are explained (Section 3.1). Then, the assessment of each criterion is detailed, specifying how the information was obtained (section 3.2).

\subsection{Data gathering methods and fieldwork}

The evaluation of the MHP projects started with an analysis of historical data to record the energy production, technical operator annotations, failure reports, etc. This information was obtained in the CVG library (southern 
Venezuela). Using this information, the causes of most common failures were identified (management, maintenance, etc.). Next, monthly reports of the company managing the projects (EDELCA) were analyzed, reflecting the long-term technical performance of the MHP (EDELCA, 2006). Complementarily, the 6 communities were visited in order to collect in situ data. On one hand, technical checks were made to identify the environmental and visual impact of the projects, the possible waste and the physical conditions of equipment. On the other hand, 6 structured interviews were held with representatives of Community Organizations and the Pemón sociopolitical leaders, as well as technicians and engineers of EDELCA. Moreover, surveys were conducted in more than 100 houses, a representative sample of beneficiaries (Lillo et al., 2015a; 2015b). The average duration of each survey was around 15-20 minutes, taking 7 days to carry them out. The questionnaire was organised in 5 sections, focusing on the main aspects that influence projects sustainability: (1) rational use of energy and the environment; (2) demand and electricity consumption; (3) basic services; (4) education level and productive activities, and (5) perception of service quality.

\subsection{Criteria definition and evaluation}

The environmental dimension of sustainability is evaluated by means of two criteria:

- Emission mitigation, is defined as the volume of $\mathrm{CO}_{2}$ avoided due to the use of renewable energy technologies (MHP) instead of diesel generators. It is estimated from the historical record of energy production, technical operator annotations, failure reports, etc. This information is obtained from historical data and is compared with typical emissions in diesel off-grid rural electrification projects (López-González et al., 2018a).

- Impact on local ecosystems, is defined as the visual or physical harm that electrification systems have on the local communities' natural environment. This criterion is assessed during the visits to the communities.

The technical dimension of sustainability is evaluated by means of two criteria:

- Adequacy, is defined from the comparison between the minimum adequacy threshold (considering the International Energy Agency, IEA, reference: $250 \mathrm{kWh} / \mathrm{year}$ ), and the design values and average consumption rates of the benefited houses (IEA, 2014). This value is assessed according to the 
historical record of energy production, technical operator annotations, failure reports, etc. This information is obtained from historical data.

- Reliability, is defined as the users' perception of the recurrence of interruptions in the electricity supply and their main causes, assessed through surveys of beneficiary families.

The socioeconomic dimension of sustainability is evaluated according to three criteria:

- Education, is the impact that electrification has had on access, quality and continuity in basic and secondary education among people. This is assessed through surveys of beneficiary families.

- Health, is the impact that electrification has had on the improvement of health conditions; particularly those relating to food, water and access to health services. This is assessed through surveys considering refrigeration equipment, electrified and equipped sanitary services, and the electrical impact on healthy drinking water conditions.

- Productivity, is the impact that electrification has had on the improvement of family incomes, the development of new productive activities, the innovation and the productive capacity of communities. This is assessed through surveys of beneficiary families.

The institutional dimension of sustainability is evaluated by means of one criterion:

- Institutional alignment, refers to the management of different public and/or private institutions in favor of the sustainable development of electrified communities according to an electrification policy. It is assessed through the structured interviews conducted with representatives of Community Organizations and the Pemón sociopolitical leaders, as well as technicians and engineers of EDELCA.

\section{RESULTS, DISCUSSION AND ENERGY POLICY IMPLICATIONS}

The following discussion sections are related to each of the results corresponding to long-term sustainability in the four dimensions considered for the evaluation. In addition, the policy implications that results may have on energy access are discussed. 


\subsection{Environmental dimension results}

From the analysis of the electrification projects, an estimated $3.19 \mathrm{GWh} /$ year of energy is consumed from the MHP technology (MPPEE, 2013). Considering an emission factor of $0.607 \mathrm{~kg} \_\mathrm{CO}_{2} / \mathrm{kWh}$, for a generation system based on community diesel generators (López-González et al., 2018a), the annual mitigation of the MHP projects is 1.963 GTon_ $\mathrm{CO}_{2} /$ year. If domestic diesel generators were considered at each house, the emission mitigation would be 4.181 GTon_ $\mathrm{CO}_{2} /$ year. However, attention should be paid to the negative impact of climate change, extending longer dry seasons during ENSO and drought periods, while negatively affecting the performance of MHP. Indeed, revision of historical reports showed droughts tend to be increasingly longer, so diesel consumption and emissions may increase in the future. In this regard, technical improvements are still necessary to minimize the use of diesel backup generators or to utilize PV backups that reduce emissions to zero (EDELCA, 2002).

Regarding the impact on the local ecosystems, the turbines developed by EDELCA (Wonken, Canaima, Ciudadela and Arautamerú) are equipped with a constant relief mechanism, which eliminates the need for other pressure regulation mechanisms that are restricted due to their impact on the natural landscape and have very limited impact on the river fauna and flora (Barei, 1994). Although a short-term and very local deforestation was caused, all deforested land was replenished with the seeds of native species, which guarantees the subsistence of the native flora and fauna, conserving the elements of the original ecosystem. In addition, the powerhouses of the MHP developed by EDELCA are built according to the architectural style of the houses of the area (Arautamerú, Wonken and Canaima). Hydraulic systems, such as cooling systems, are installed in closed circuits, to avoid oil spills that could contaminate the water and worsen its quality levels. Additionally, the generation of hydroelectricity reduces the use of diesel plants that require non-renewable fuels (EDELCA, 1996).

Considering all these aspects, the environmental dimension of sustainability for the studied cases is positive.

\subsection{Technical dimension results}

With regards to adequacy, household appliances and the number of usage hours are determined from the surveys, thus estimating an average consumption of $4.38 \mathrm{kWh} /$ day per house, which is $40 \%$ higher than the average consumption in rural communities connected to the national grid in Venezuela (Rojas-Zerpa and 
Yusta, 2015). In addition, the estimated value corresponds to around 1,600 $\mathrm{kWh} /$ year, which is more than seven times the minimum threshold proposed by the IEA. Therefore, the performance of the MHP in terms of electricity supply has been sufficient to cover basic demand and, moreover, to enable a change in the life quality of users during the projects' lifetime.

With regard to reliability, all the micro-hydroelectric power plants have been operating continuously for long periods, ranging from 23 years in the case of Canaima to 60 years in that of Kavanayén. However, there have been failures in all the projects during their lifetime, with the overload of distribution networks (38\%) and dry periods $(31 \%)$ being the main causes, while lightning strikes $(23 \%)$ and distribution line faults $(8 \%)$ are less frequent. A detailed review of each failure cause is provided below:

- Electrical overload: nowadays, in four MHP, the maximum demand of communities has already reached the installed capacity; for instance, in Arautamerú after 19 years (2007) and in La Ciudadela after 13 years (2007). Those communities are very close to the trunk road that crosses La Gran Sabana, so the trade of handicrafts and the construction of restaurants and inns has led to a rapid increase in electricity demand. In contrast, Kavanayén and Wonken have been working below the maximum capacity for a longer period, 57 and 33 years respectively. This is because they were designed with a significant loose capacity (as well as Kamarata) as they are particularly isolated and can be only accessed by air, river or four-wheel-drive vehicles. Although at high demand hours the farthest houses have voltage fluctuations that have shortened the lifetime of some appliances, most inhabitants confirm that the electricity service is stable.

- Dry season: all the MHP are susceptible to flow variations in the river basins where they have been located, even causing interruptions in the electricity supply during droughts. The most affected are Kavanayén and Wonken, because they are in low-flow rivers and do not use dams (as in Kamarata). In these cases, diesel generators have been installed as backup, thus ensuring continuous electricity supply throughout the year.

- Lightning and distribution network: there are a close relationship, since lightning impacts the electrical distribution system, causing interruptions in the electricity service. Due to the low population density, most of the water, telecommunications and electricity distribution services are aerial, which makes 
them vulnerable to weather events (Martínez et al., 2003). On the other hand, the distribution network has also deteriorated due to high humidity levels.

Thus, initial designs with significant spare capacity are recommended, when possible, to reduce failures. However, despite the existence of failures, almost all users are satisfied and $93.8 \%$ of the surveyed population qualified the MHP electricity service as good, very good or excellent. In communities having larger risk in drought periods, the service quality remains satisfactory due to the diesel backup. Thus, the addition of a diesel backup guarantees a better service and the project's success. Considering users' satisfaction and the operating time of the technical dimension of sustainability, the studied case is positive. In short, the existing failures do not represent a challenge that cannot be solved.

\subsection{Socioeconomic dimension results}

In terms of education, the MHP projects have allowed conditions in primary and secondary schools to be as good as those of any other rural community electrified through the national grid. In particular, $43.8 \%$ of the houses have desktop computers and 50\% have "Canaima" laptops delivered to children by the national government, under the program "Canaima Educativo" (Educational Canaima) (AVN, 2014). In recent years, the studied communities have got internet access through programs from the ESC and the national telecommunications company. Thus, children can download educational updates on their laptop either from home or school (SITEAL, 2014). In addition, due to electricity and education improvements, the attendance rate has significantly increased and is currently higher than the national average. Electricity availability in class (i.e. allowing the use of multimedia techniques) makes attendance to formal education attractive for children and parents. School attendance in basic education (from 7 to 12 years) is $87.0 \%$, and in secondary education (from 13 to 17 years) is $73.3 \%$, whereas the national rates are $46.6 \%$ and $8.3 \%$, respectively (Regnault, 2006). Moreover, the dropout rate at the secondary level is much lower. Regarding access to university, at the national level only $1.2 \%$ of the rural indigenous population have university education (Regnault, 2006), while in analyzed communities this rate is $14.7 \%$. Finally, the literacy rate is $92.6 \%$, which exceeds the $68.6 \%$ national average in indigenous rural communities (Regnault, 2006).

Regarding MHP impact on health, $75 \%$ of the houses in the electrified communities have been able to install refrigerators or freezers. These facilities are very important for the conservation of food in a diet based on river 
fish, considering both the high levels of humidity and that the temperatures in La Gran Sabana range between 18 and $23^{\circ} \mathrm{C}$ (FDA, 2011; INE, 2014). Refrigerators and freezers allow the proper preservation of food, particularly reducing infant mortality (Rodríguez de Sifontes and Betancourt, 2015). Moreover, electric lighting replaces kerosene lamps, which emit gases and particles that can cause asthma and infectious diseases such as tuberculosis as well as increae the risk of cancer (Lam et al., 2012). In addition, the communities have electrified primary health centers (Figure 9). Moreover, in Kavanayén, Kamarata and Arautemerú there are drinking water distribution networks, as pumping stations have been electrified.

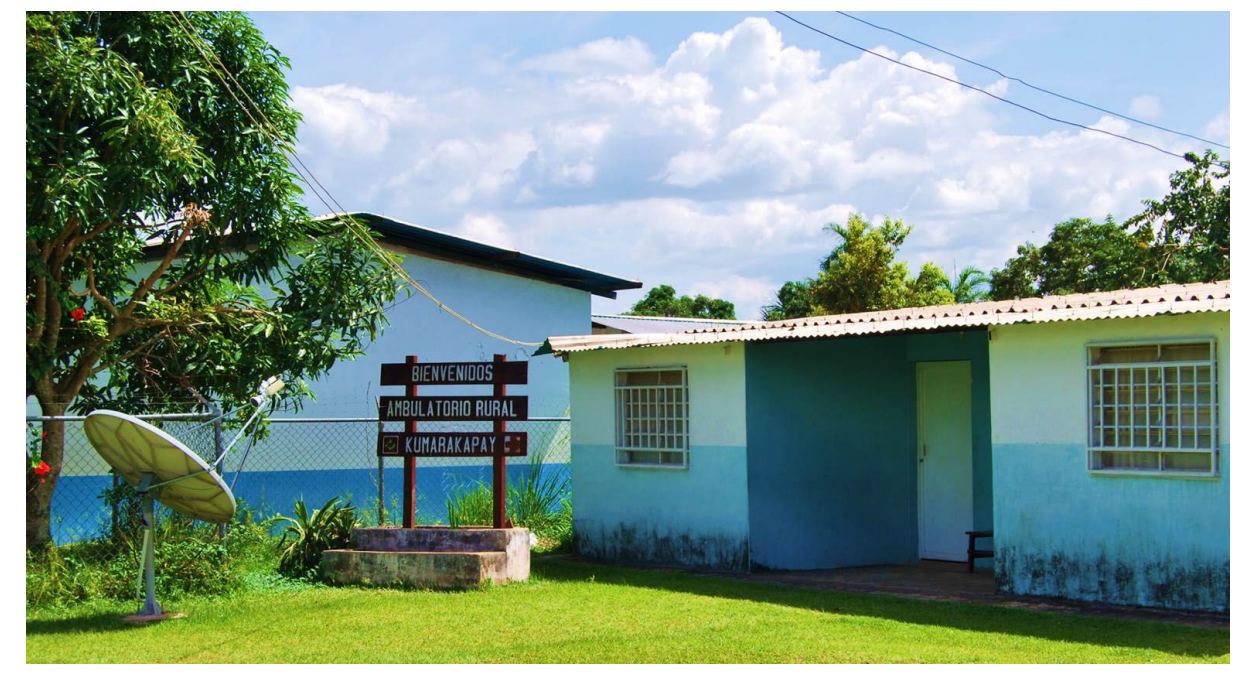

Figure 9. Health center in San Francisco de Yuruaní and telecommunications antenna for internet

Regarding productivity, $30 \%$ of the energy from MHP is used for productive purposes, according to the historical generation record and field demand surveys. The communities of Kavanayén, Kamarata, Arautamerú and La Ciudadela are dedicated primarily to tourism and lodging, so electrification has been fundamental in providing higher quality services to tourists. In particular, eco-tourism has increased with low environmental impact activities that allow the population to safeguard their natural and cultural environment. In Canaima, the electricity supply has allowed the establishment of small businesses such as internet or laundry services (run by women) that have significantly raised the income levels (EDELCA, 1996). Small businesses selling food, water and soft drinks have proliferated, and many inns provide internet and wi-fi services, facilitating payment by credit and debit cards. Moreover, the ESC has carried out repair work on the roads that connect villages such as Kavanayén and Wonken with nearby communities, promoting opportunities for the commercialization of local products and easier access for tourists. In addition, the incorporation of techniques for the conservation 
and management of natural resources has brought an increase in the productivity of the land (EDELCA, 2004). The breeding of cattle was also introduced and very well received by natives, as it represents a varied source of food whose surplus is occasionally sold (Gutierrez-Salazar, 2004). Indeed, since the beginning of the Catholic missions, the indigenous population have learned to improve their sowing capacity in conucos, a small plot of land dedicated to minor fruits, almost without irrigation (EDELCA, 2004). In Kamarata, projects from non-governmental organizations such as the Eposak Foundation stand out: an agro-productive center for sowing vegetables, legumes and plants, which are not usually harvested in conucos. In San Ignacio de Yuruaní, a large farm has been built, using irrigation with electric pumps, and the population obtain profits from selling agricultural products. Refrigeration has also helped local fishermen to increase their profits, because they are able to store fish for longer periods before it is sold to restaurants and inns. The improvement in income levels guarantees economic resources for the maintenance and self-management of MHP.

Considering the advances in education, health and productivity, the socioeconomic dimension of sustainability for the studied cases is positive. Even though electricity access itself eases and improves these aspects, programs complementing electricity and promoting its efficiency are recommended in order to increase the positive impact.

\subsection{Institutional dimension results}

Regarding the institutional alignment, the Mayú (“joint work” in Pemón language) program brought together the efforts of EDELCA, the National Government, the Government of Bolívar state, the Municipality of La Gran Sabana and Community Organizations. Several parallel initiatives have been launched, promoting and strengthening the comprehensive development of the population by making efficient use of electricity while respecting the local environment. For instance, in Arautamerú, community centers were electrified to hold workshops and training courses on the management, productive and sustainable use of natural resources (EDELCA, 2004). Through this training, environmentally friendly technologies have been incorporated to strengthen the traditional productive processes of the indigenous population. The interviews and surveys have shown users' satisfaction is directly related to the implemented management model. Thus, the institutional dimension, through the appropriate alignment of institutions involved in rural electrification, is the key issue 
for projects' sustainability in terms of improving the impact and results of the environmental, technical and socioeconomic dimensions.

From the perspective of the environmental dimension, the institutional alignment between electricity companies, local governments, indigenous communities, religious missions and other agents has been motivated by the conservation of the Caroní basin. This river has a strategic importance at national and regional level, given its richness in biodiversity, the potential for tourism and the provision of more than $60 \%$ of Venezuelan electricity (MPPEE, 2013). Consequently, electrification promoters have worked together in order to promote sustainable development in the indigenous communities.

In terms of the technical dimension, the institutional alignment has been channeled to progressively improve the MHP technology, so that it adapts better to the local conditions. This minimizes the $\mathrm{CO}_{2}$ emissions and the impact on local ecosystems, while suitability and reliability are maximized. In this regard, the most successful milestone is the development of turbines adapted to regional characteristics. From the experience of the first two projects, EDELCA developed the Banki-Edelca turbines, which were later continuously improved until the third generation for the later projects. The institutional alignment enabled Religious Missions and Community Organizations to provide the technical knowledge from previous experiences, as well as social and environmental requirements. EDELCA was able to provide technical resources for the development and improvement of turbines and National and Regional Governments could provide a national market for this technology, thus ensuring that effort is not invested in a single project but a succession of projects within a rural electrification program. This is corroborated by the low visual impact and the non-intervention in fragile ecosystems, particularly in the later projects, as well as a vast majority of users satisfied with the electricity service.

In terms of the socioeconomic dimension, the institutional alignment has resulted in the use of electricity to respond to the specific needs of the population. Thus, access to new technologies and materials (such as laptops) has improved education levels. The increase in health conditions (such as refrigerated food) not only helps the local population, but also attracts new tourists and subsequent incomes. Also, some programs have been launched to raise incomes by implementing new agricultural and manufacturing techniques or improving tourist commodities (such as wi-fi) that have a positive impact on community incomes. All of this leads to the 
differences observed between the researched case studies and other indigenous communities electrified through the national grid, where the lack of coordination between institutions has limited the comprehensive development of the population. Historically, in Venezuela, the electricity tariff has been very low, and even lower in the last 20 years. According to the average daily consumption in the indigenous communities visited, the monthly burden of the electricity bill hardly reaches $2 \%$ of family incomes.

Over the years, a gradual reordering of stakeholders has been observed (Figure 2), affecting the organization of the management model. In any case, the electrification projects have remained successful and the changes have sought to ensure their operation and maintenance over time. Therefore, the institutional dimension of sustainability for the researched case studies is positive. However, it should be noted that some users mention a deterioration in the electricity service since 2014, coinciding with a national crisis and the difficulties of National and Regional Governments supporting the program. This reinforces the idea of the need for an adequate institutional alignment to achieve global sustainability of MHP projects.

\section{CONCLUSION AND POLICY IMPLiCATIONS}

Although micro-hydroelectric power plants (MHP) are generally considered a suitable option for rural electrification in remote communities, there is a lack of empirical sustainability evaluations to assess the longterm performance of the projects. In this research, the sustainability of 6 MHP in indigenous communities located in La Gran Sabana (Bolívar state, Venezuela) is evaluated after 20 to 60 years of continuous operation. Three projects (Kavanayén, Kamarata and Wonken) were started by Capuchin missionaries, while the other three (Arautamerú, La Ciudadela and Canaima) were developed by the Venezuelan electricity company EDELCA, based on Banki turbines. For the evaluation, four sustainability dimensions are considered: environmental, technical, socioeconomic and institutional. Criteria and indicators are defined for each dimension to evaluate different aspects of the MHP projects' impact, which are assessed using information from historical record databases, user surveys, technical visits and structured interviews with technicians, engineers and beneficiaries.

The results show the relevance of the institutional dimension and a long-term sustainable electrification policy, through an adequate alignment between the institutions involved in rural electrification, in strengthening the long-term sustainability of the reviewed electrification projects. Hence, the collaboration between national, 
regional and local institutions has led to the progressive improvement of MHP in order to minimize the impact on ecosystems and mitigate emissions. This could even be improved by investing in RET-based backup systems, to reinforce the environmental dimension of sustainability. In addition, stakeholders' efforts have favored the development and improvement of adapted turbines, responding to the local needs in an adequate and reliable manner and consolidating the technical dimension of sustainability. Finally, the launching of parallel programs in order to make an efficient use of electricity has helped to support education, health and productive conditions of population, enhancing the socioeconomic dimension of sustainability. Successive changes in the institutional alignment are an evidence of the importance of the institutional dimension throughout projects lifetime.

This research identifies key issues to be taken into account by decision-makers in further rural electrification projects. The Venezuelan experience provides elements for the promotion and development of more and better rural electrification programs based on MHP, considering the experience gained and lessons learned from projects with a long-term historical data, in environments with similar features and constraints in the developing countries of South America, Asia or Africa.

\section{ACKNOWLEDGMent}

This research was funded by the Spanish Ministry of Science and Innovation (project ENE 2015-67253-R cofinanced by FEDER) and the Centre for Cooperation Development (CCD) of the Universitat Politècnica de Catalunya-Barcelona TECH (UPC). It has been possible thanks to the kind collaboration of the engineers Angel López V. and Leonardo López G. (PDVSA), Eposak Foundation and community councils of electrified communities in the Bolivar state of Venezuela.

\section{REFERENCES}

Abbasi, T., Abbasi, S.A., 2011. Small hydro and the environmental implications of its extensive utilization. Renew. Sustain. Energy Rev. 15, 2134-2143. doi:10.1016/j.rser.2010.11.050

Angosto-Fernández, L., 2013. Lugar, identidad y producción en la Gran Sabana, Venezuela. Rev. Colomb. Antropol. 49, 11-43.

AVN, 2014. UNESCO Recognizes Venezuela's Canaima Program as Example for the Region [WWW 
Document]. Latest News. URL http://www.embavenez-us.org/_boston/news.php?nid=5705 (accessed 9.3.17).

Barei, J., 1994. Investigación y Tecnología en EDELCA. Entrecorrientes 3.

Blanco, C.J.C., Secretan, Y., Mesquita, A.L.A., 2008. Decision support system for micro-hydro power plants in the Amazon region under a sustainable development perspective. Energy Sustain. Dev. 12, 25-33. doi:10.1016/S0973-0826(08)60435-4

Bracken, L.J., Bulkeley, H.A., Maynard, C.M., 2014. Micro-hydro power in the UK: The role of communities in an emerging energy resource. Energy Policy 68, 92-101. doi:10.1016/j.enpol.2013.12.046

CORPOELEC, 2014. MPPEE, CORPOELEC y FUNDELEC realizaron visita a modelos hidráulicos en Macagua [WWW Document]. Noticias. URL http://www.corpoelec.gob.ve/noticias/mppee-corpoelecy-fundelec-realizaron-visita-modelos-hidráulicos-en-macagua (accessed 8.18.17).

Cottrell, S.P., Vaske, J.J., Roemer, J.M., 2013. Resident satisfaction with sustainable tourism: The case of Frankenwald Nature Park, Germany. Tour. Manag. Perspect. 8, 42-48. doi:10.1016/j.tmp.2013.05.005

Drinkwaard, W., Kirkels, A., Romijn, H., 2010. A learning-based approach to understanding success in rural electrification: Insights from Micro Hydro projects in Bolivia. Energy Sustain. Dev. 14, 232-237. doi:10.1016/j.esd.2010.07.006

EDELCA, 2008. Electrificación del Caroní, C.A. Informe Anual 2007. Caracas.

EDELCA, 2006. Electrificación del Caroní, C.A. Memoria Social 2005. Puerto Ordaz.

EDELCA, 2004. Electrificación del Caroní, C.A. Memoria Social 2003. Puerto Ordaz.

EDELCA, 1996. Electrificación del Caroní, C.A. Informe Anual 1995. Puerto Ordaz.

EDELCA, 1995. Electrificación del Caroní, C.A. Informe Anual 1994. Puerto Ordaz.

EDELCA, 1991. Desarrollo de turbina Banki por EDELCA, in: PROMIHDEC (Ed.), Encuentro 
Latinoamericano En Pequeños Aprovechamientos Hidroenergéticos 1991. PROMIHDEC, Lima, p. 300.

Fundelec, 2015. Pequeñas Centrales hidroeléctricas generarán energía para comunidades lejanas en el estado Mérida [WWW Document]. Energías Renov. URL http://www.fundelec.gob.ve/?p=1999 (accessed 8.18.17).

Gollwitzer, L., Ockwell, D., Muok, B., Ely, A., Ahlborg, H., 2018. Rethinking the sustainability and institutional governance of electricity access and mini-grids: Electricity as a common pool resource. Energy Res. Soc. Sci. 39, 152-161. doi:10.1016/j.erss.2017.10.033

Gutierrez-Salazar, M., 2004. 80 años sembrando evangelio: La iglesia por las tierras de la Gran Sabana, Guayana y Delta Amacuro, Primera. ed. Corporación Venezolana de Guayana, Ciudad Guayana.

IEA, 2017. Energy Access Outlook 2017: From poverty to prosperity. Paris.

Ilskog, E., 2008. Indicators for assessment of rural electrification-An approach for the comparison of apples and pears. Energy Policy 36, 2665-2673. doi:10.1016/j.enpol.2008.03.023

INE, 2014. XIV Censo Poblacional de Población y Vivienda. Resultados por Entidad Federal y Municipio del Estado Bolívar. Caracas.

Instituto Nacional de Estadística, 2017. Censo 2011 Redatam [WWW Document]. URL http://www.redatam.ine.gob.ve/Censo2011/index.html (accessed 3.24.17).

International Energy Agency, 2014. Africa Energy Outlook. A focus on the energy prospects in sub-Saharan Africa, World Energy Outlook Special Report, International Energy Agency Publication. doi:https://www.iea.org/publications/freepublications/publication/africa-energy-outlook.html

IRENA, 2017. 2016 a Record Year for Renewables, Latest IRENA Data Reveals [WWW Document]. Renew. Energy Capacit. Stat. 2017. URL http://www.irena.org/News/Description.aspx?NType=A\&mnu=cat\&PriMenuID=16\&CatID=84\&News _ID=1486 (accessed 4.26.17). 
Jawahar, C.P., Michael, A., 2017. A review on turbines for micro hydro power plant. Renew. Sustain. Energy Rev. 72, 882-887. doi:10.1016/j.rser.2017.01.133

Jia, J., Punys, P., Ma, J., 2017. Small Hydropower (SHP) Development, in: Chen, Y. (Ed.), Handbook of Climate Change Mitigation and Adaptation. Springer International Publishing, pp. 2085-2131. doi:10.1007/978-1-4614-6431-0

Jimenez, R., 2017. Barriers to electrification in Latin America: Income, location, and economic development. Energy Strateg. Rev. 15, 9-18. doi:10.1016/j.esr.2016.11.001

Khan, R., 2015. Small Hydro Power in India: Is it a sustainable business? Appl. Energy 152, 207-216. doi:10.1016/j.apenergy.2014.11.063

Khennas, S., Barnett, A., 2000. Micro-hydro power: an option for socio-economic development, in: Sayingh, A. (Ed.), World Renewable Energy Congress If"1 (WREC2000). Elsevier Ltd, Rugby, UK, pp. 15111517.

Lakhanpal, S., 2018. Why small hydroelectric projects are not the answer to India's clean energy woes $\mid$ The News Minute [WWW Document]. News Minute. URL https://www.thenewsminute.com/article/whysmall-hydroelectric-projects-are-not-answer-india-s-clean-energy-woes-88815 (accessed 3.1.19).

Lam, N.L., Smith, K.R., Gauthier, A., Bates, M.N., 2012. Kerosene: a review of household uses and their hazards in low- and middle-income countries. J. Toxicol. Environ. Health. B. Crit. Rev. 15, 396-432. doi:10.1080/10937404.2012.710134

Lillo, P., Ferrer-Martí, L., Boni, A., Fernández-Baldor, Á., 2015a. Assessing management models for offgrid renewable energy electrification projects using the Human Development approach: Case study in Peru. Energy Sustain. Dev. 25, 17-26. doi:10.1016/j.esd.2014.11.003

Lillo, P., Ferrer-Martí, L., Fernández-Baldor, Á., Ramírez, B., 2015b. A new integral management model and evaluation method to enhance sustainability of renewable energy projects for energy and sanitation services. Energy Sustain. Dev. 29, 1-12. doi:10.1016/j.esd.2015.08.003

López-González, A., Domenech, B., Ferrer-Martí, L., 2018a. Lifetime, cost and fuel efficiency in diesel 
projects for rural electrification in Venezuela. Energy Policy 121, 152-161.

doi:10.1016/j.enpol.2018.06.023

López-González, A., Domenech, B., Ferrer-Martí, L., 2018b. Sustainability and design assessment of rural hybrid microgrids in Venezuela. Energy 159, 229-242. doi:10.1016/j.energy.2018.06.165

López-González, A., Domenech, B., Gómez-Hernández, D., Ferrer-Martí, L., 2017. Renewable microgrid projects for autonomous small-scale electrification in Andean countries. Renew. Sustain. Energy Rev. 79, 1255-1265. doi:10.1016/j.rser.2017.05.203

Martínez, M., Ramírez, J., Montaño, R., 2003. Lightning Activities in Venezuela using the Lightning Imaging Sensor of TRMM NASA Project. Rev. Técnica la Fac. Ing. Univ. del Zulia 26, 127-139.

MPPEE, 2013. Anuario estadístico 2013: Sector Eléctrico Venezolano. doi:201108DC35

Novo Torres, I., Díaz Martín, D., 2007. Informe final de la evaluación del Parque Nacional Canaima, Venezuela, como sitio de Patrimonio Natural de la Humanidad. Caracas.

Paish, O., 2002. Small hydro power: Technology and current status. Renew. Sustain. Energy Rev. 6, 537556. doi:10.1016/S1364-0321(02)00006-0

Pang, M., Zhang, L., Ulgiati, S., Wang, C., 2015. Ecological impacts of small hydropower in China: Insights from an emergy analysis of a case plant. Energy Policy 76, 112-122. doi:10.1016/j.enpol.2014.10.009

Pigaht, M., van der Plas, R.J., 2009. Innovative private micro-hydro power development in Rwanda. Energy Policy 37, 4753-4760. doi:10.1016/j.enpol.2009.06.039

Regnault, B., 2006. Asistencia y permanencia escolar de la niñez y adolescencia indígena en Venezuela. Caracas.

REN21, 2016. Renewables 2016: Global Status Report. Paris.

Rodrígez-Betancourt, R., González-Aguirre, J., 2000. El manejo de los recursos hídricos en Venezuela (No. 18), Latinoamericana. México, D.F. 
Rodríguez de Sifontes, Y., Betancourt, K., 2015. Análisis de la situación sobre la práctica de lactancia materna en Venezuela. Fondo de las Naciones Unidas para la Infancia-UNICEF Venezuela, Caracas.

Rojas-Zerpa, J.C., Yusta, J.M., 2015. Application of multicriteria decision methods for electric supply planning in rural and remote areas. Renew. Sustain. Energy Rev. 52, 557-571. doi:10.1016/j.rser.2015.07.139

Sachdev, H.S., Akella, A.K., Kumar, N., 2015. Analysis and evaluation of small hydropower plants: A bibliographical survey. Renew. Sustain. Energy Rev. 51, 1013-1022. doi:10.1016/j.rser.2015.06.065

Schnitzer, D., 2014. Microgrids for Rural Electrification : A critical review of best practices based on seven case studies Microgrids for Rural Electrification : A critical review of best practices. United Nations Foundation, Berkeley.

Serru, K., 2014. Development of a framework for the assessment of the resilience of off-grid renewab le energy community projects in Odisha, India. Heriot Watt.

Sharma, A.K., Thakur, N.S., 2015. Resource potential and development of small hydro power projects in Jammu and Kashmir in the western Himalayan region: India. Renew. Sustain. Energy Rev. 52, 1354 1368. doi:10.1016/j.rser.2015.08.024

SITEAL, 2014. Canaima Educativo [WWW Document]. Políticas Educ. URL http://www.siteal.iipe.unesco.org/politica/832/canaima-educativo (accessed 9.3.17).

Smith, S.C., Ubilava, D., 2017. The El Niño Southern Oscillation and economic growth in the developing world. Glob. Environ. Chang. 45, 151-164. doi:10.1016/j.gloenvcha.2017.05.007

Terrapon-Pfaff, J., Dienst, C., König, J., Ortiz, W., 2014. A cross-sectional review: Impacts and sustainability of small-scale renewable energy projects in developing countries. Renew. Sustain. Energy Rev. 40, 1-10. doi:10.1016/j.rser.2014.07.161

United Nations, 2015. Transforming our world: The 2030 agenda for sustainable development, A/RES/70/1. doi:10.1007/s13398-014-0173-7.2 
van de Walle, D., Ravallion, M., Mendiratta, V., Koolwal, G., 2013. Long-term impacts of household electrification in rural India, Policy Research Working Paper Series. doi:10.1093/wber/lhv057

Yadoo, A., Cruickshank, H., 2012. The role for low carbon electrification technologies in poverty reduction and climate change strategies: A focus on renewable energy mini-grids with case studies in Nepal, Peru and Kenya. Energy Policy 42, 591-602. doi:10.1016/j.enpol.2011.12.029 